\title{
Music preferences with regard to music education, informal influences and familiarity of music amongst young people in Croatia
}

\author{
Snježana Dobrota ${ }^{1}$ and Ina Reić Ercegovac ${ }^{2}$ \\ ${ }^{1}$ Teslina 12, 21000 Split, Croatia \\ ${ }^{2}$ Put iza nove bolnice 10c, 21000 Split, Croatia \\ dobrota@ffst.hr, inareic@ffst.hr
}

The aim of this research was to investigate the relationship between music preference and music education, informal influences (attending classical music concerts and musical theatre productions) and familiarity of music. The research included students of the Faculty of Humanities and Social Sciences, University of Split $(\mathrm{N}=341)^{1}$. The results showed that participants usually listen to popular music in their leisure time and that popular music is their most preferred music style. A positive relationship between familiarity and preferences was found but this effect was not unambiguous. A relationship between music preferences and secondary school music education was not found, but those participants who attended music school preferred some music styles more than did those participants who did not attend music school. There was a significant correlation found between the frequency of attending classical music concerts and preferences for classical music, jazz and world music. Finally, the results indicated that people who frequently attend musical theatre productions have significantly higher preferences for jazz and world music. The authors pointed to the problem of unattractiveness of music lessons in secondary schools and suggest possible solutions to the problem.

\section{Introduction}

Music has a very important role in people's lives. It fulfils a number of different functions, and we can listen to music in different conditions and contexts. Music preferences are defined as preferring one piece of music over another at a certain point in time, while music taste refers to the general patterns of preferences of the individual over an extended period of time (Hargreaves, North \& Tarrant, 2006).

Within experimental aesthetics, which investigates ways of responding to a variety of art forms, two approaches have been developed. The author of the first of these is Berlyne (1971), who studied the effect of music and other artistic forms on the physiological arousal of the individual. He pointed out that the preferences for artistic and music stimuli were related to their arousal potential. 'Music with an intermediate degree of arousal potential is preferred the most while this degree of liking gradually decreases towards the extremes of arousal potential' (North \& Hargreaves, 2008, p. 77). What this means is that the relationship between preferences and arousal potential shows an inverted- $U$ shape. 
According to Berlyne (1971) there are three groups of variables that mediate in arousal potential: psychophysical variables, which relate to the physical properties of the stimulus, such as tempo or dynamics, ecological variables, which refer to the meaningfulness of musical work and collative variables which relate to the informational properties of music, such as complexity level or familiarity with the musical piece.

Another approach to music preferences, the preferences for prototypes model (Martindale \& Moore, 1988), is based on cognitive psychology. This approach rests on the idea that individuals prefer those things that can be easily classified, so prototypicality of artistic objects, which refers to the extent to which a music work is typically representative of a style which it represents, is a stronger determinant of preferences than their arousal potential.

Hargreaves, Miell and MacDonald (2005) are the authors of the Reciprocal feedback model of musical response that indicates that the responses to music are determined by variables associated with the listener (gender, age, formal and informal influences etc.), music (musical styles, collative variables, prototypicality, performance contexts, etc.) and listening situation (social and cultural contexts, everyday situations, the presence/absence of other people, etc.). Each of the three groups of variables can also affect the other two, and these effects are bidirectional. For the purposes of this study, formal learning is defined as occurring within an organised and structured context and is designed as learning. It may lead to a formal recognition and is intentional from the learner's perspective. Nonformal learning consists of learning embedded in planned activities that are not explicitly designated as learning, but which contain an important learning element. It is intentional from the learner's perspective. Informal learning is defined as learning resulting from daily life activities related to work, family or leisure. It is not structured in terms of learning objectives, learning time and learning support and does not lead to certification (Colardyn \& Bjornavold, 2004, p. 71). There is scholarly consensus that formal music learning is associated with classical music, jazz etc., and that the world of informal music learning is often connected to popular music forms (Vitale, 2011, pp. 1-2; Green, 2008).

Considering the issue of developing music preferences in lifespan perspective, Hargreaves (1982) uses the term open-earedness, which LeBlanc explains as tolerance of the listener' for various musical styles (1991, p. 4). LeBlanc poses four hypotheses about the development of music preference as follows: '(1) younger children are more open-eared, (2) open-earedness declines as the child enters adolescence, (3) there is a partial rebound of open-earedness as the listener matures from adolescence to young adulthood, and (4) open-earedness declines as the listener matures to old age' (LeBlanc, 1991, pp. 36-38).

Hargreaves, Comber and Colley (1995) examined the influence of age, gender and music training on musical preferences of British secondary school students of the 11-12 to 15-16-year-old age-groups. There were no significant age/gender interactions, but there was a general decline in liking for music with age, especially for classical music. One of these stereotypical assumptions is that girls expressed preferences for a wider range of styles, especially those 'serious' ones, as opposed to boys. With regard to the influence of gender on music preferences, researchers mostly confirm that women generally have more positive attitudes towards music than men (Crowther \& Durkin, 1982; Eccles et al., 1993; Reić Ercegovac \& Dobrota 2011). Their research suggests that women prefer 'softer' music styles, such as mainstream pop music, and men prefer 'harder' music styles, such as hard rock or heavy rock (Christenson \& Peterson 1988; Robinson, Weaver \& Zillmann 1996). 
Results of numerous studies that have investigated the relationship between music preference and music education indicate their close relationship, at least in the case of preferences for complex music, such as classical music. This is consistent with the Berlyne theory (1971) that increased musical ability or training goes along with decreased subjectively perceived complexity, so that pieces of music which were initially at an optimal level of complexity shift to the left half of the inverted $U$-shape relationship between complexity and preference (Berlyne, 1971). However, in the case of preferences for popular music, studies have not confirmed the important role of music education (Palmquist, 1990). In addition to education, preferences for classical music are associated with socioeconomic status. North and Hargreaves (2007a, 2007b, 2007c) point out that fans of sophisticated musical styles, such as classical music, often have higher income and higher levels of education, while fans of rap music or electronic music tend to have lower socioeconomic status.

Analysing the relationship between familiarity and subjective complexity of a music piece, North and Hargreaves (2008, pp. 81-82) point out that with increasing familiarity of musical works its objective complexity remains unchanged, but subjective complexity of the music is reduced. (Objective complexity of music refers to the statistical probability of one note following another, relative to the entirety of Western music. On the other hand, subjective measures of complexity concentrate on the degree of complexity that a listener perceives the music to possess (North \& Hargreaves, 2008, p. 81)). Each repeated listening of a musical work causes its move from the right to the left side of the inverted U-shape which represents the relationship between complexity and preference. The aforementioned authors illustrated this phenomenon by analysing the preferences of three songs after their first listening. The first song had a low level of complexity and the examined listeners did not like it, the other song had moderate complexity and listeners liked it most, while listeners did not like the third song, which was the most complex. After repeated listening of those three songs, and because of the increased familiarity that reduces the subjective complexity of the music, the differences in preferences were observed. The first song became even less popular than after the first listening, the preferences for the second song were also declining, while the third song has climbed up the inverted $U$-shape to the peak. Results of numerous studies confirmed that students prefer music they are familiar with. For example, Getz (1966) pointed out that seventh-grade students stated familiarity of music as the most important factor that contributed to their musical preferences.

Teo, Hargreaves and Lee (2008) investigate whether there were significant differences in preferences for, familiarity with, and identification of Chinese, Malay, and Indian music between adolescent students from Singapore and the United Kingdom. Singaporean girls showed greater preference for, familiarity with, and identification of the Chinese and Malay styles than did girls from the United Kingdom. Both groups rated the Indian music lowest on preference and familiarity, although the Singaporean students were better at identifying it. Positive interrelationships among familiarity, identification, and preference for these styles were found for the Chinese style but not for the Indian music.

\section{Aim of research and research problems}

The aim of this research was to examine the influence of music education, some informal factors (attending classical music concerts and musical theatre productions) and familiarity 
of music on participants' music preferences. Bearing in mind the results of some previous research (Reić Ercegovac \& Dobrota, 2011), we tested the following hypotheses in order to achieve this aim:

1. In their leisure time, participants usually listen to popular music.

2. Participants significantly prefer popular music in relation to other musical styles included in this research (heavy metal, classical, music, jazz, world music).

3. Familiarity of music has a positive effect on music preferences.

4. There are significant differences in music preferences between participants who attended grammar school in relation to those who attended vocational school.

5. Attending music school (primary or secondary) has a positive effect on the music preferences.

6. Attending classical music concerts and musical theatre productions has a positive influence on music preferences.

\section{Method}

\subsection{Participants}

A total of 341 college students of the Faculty of Humanities and Social Sciences at the University of Split took part in this study. The average age of the participants was $M=21.6$ years (range 18-28).

\subsection{Instruments}

For the purpose of this research, a questionnaire consisting of two parts was prepared. The first part consisted of questions related to sociodemographic characteristics (gender, age, completed secondary school education, attending music school, attending classical music concerts and musical theatre productions, listening to music in leisure time). The questions about gender, completed secondary school education and attending music school were formulated as closed questions with two responses. Participants were asked to write their age and the type of music they listen to in their leisure time in provided blank spaces. The questions about the frequency of attending to classical music concerts and musical theatre productions were presented with an assessment scale of four degrees (never, rarely, sometimes, often).

The second part of the questionnaire related to the research of music preferences. Music preferences were examined using a personal computer, speakers and 15 musical fragments recorded on a compact disc (Table 1), each lasting about one minute. The musical examples belonged to jazz, heavy metal, classical music, world music and popular music styles. The questionnaire of music preferences consisted of an odd number of musical fragments from the $\mathrm{CD}$ and a five-degree assessment scale ( $1=$ strongly dislike; $5=$ strongly like). Participants were also asked to assess the familiarity of each musical fragment by circling yes or no next to the each assessment scale. The musical fragments were selected by two independent experts in the field of music who offered a wider list of examples for each style out of which authors randomly selected three fragments for each genre. 
Table 1. Factor structure of music preferences questionnaire

\begin{tabular}{|c|c|c|c|c|c|c|}
\hline Performer & Music Example & $\begin{array}{l}\text { Musical } \\
\text { Style }\end{array}$ & $\mathrm{F} 1$ & F2 & F3 & F4 \\
\hline Louis Armstrong & When You're Smiling & jazz & .79 & & & \\
\hline Julian Avalos & Guajira Bonita (Peru) & world music & .58 & & & \\
\hline Claudia Gomez & Soltarlo (Colombia) & world music & .57 & & & \\
\hline Charlie Parker & I've got Rhythm & jazz & .77 & & & \\
\hline Cafe Tacuba & Esa noche (Mexico) & world music & .52 & & & \\
\hline Miles Davies & $\begin{array}{l}\text { Smoke gets in your } \\
\text { eyes }\end{array}$ & jazz & .77 & & & \\
\hline Iron Maiden & The Trooper & heavy metal & & .89 & & \\
\hline Judas Priest & Painkiller & heavy metal & & .83 & & \\
\hline Black Sabbath & Paranoid & heavy metal & & .83 & & \\
\hline Melanie Fiona & Monday Morning & pop & & & .81 & \\
\hline Jay Z Alicia Keys & Empire State of Mind & pop & & & .59 & \\
\hline Taylor Swift & You Belong With Me & рор & & & .67 & \\
\hline C. Orff & $\begin{array}{l}\text { Carmina Burana, O } \\
\text { Fortuna }\end{array}$ & classical & & & & .76 \\
\hline $\begin{array}{l}\text { Johann } \\
\text { Sebastian } \\
\text { Bach }\end{array}$ & $\begin{array}{l}\text { Toccata and Fugue in } \\
\text { D minor, BWV } \\
565 \mathrm{G}\end{array}$ & classical & & & & .75 \\
\hline \multirow[t]{7}{*}{ Georg F. Händel } & Alleluia & classical & & & & .76 \\
\hline & & Explained variance & $19 \%$ & $16 \%$ & $14 \%$ & $12 \%$ \\
\hline & & Cronbach $\alpha$ & .78 & .88 & .60 & .69 \\
\hline & & $M(s d)$ & $\begin{array}{l}20.97 \\
(4.6)\end{array}$ & $\begin{array}{l}9.11 \\
(3.25)\end{array}$ & $\begin{array}{l}11.09 \\
(2.65)\end{array}$ & $\begin{array}{l}11.25 \\
(2.64)\end{array}$ \\
\hline & & Range & $7-30$ & $3-15$ & $3-15$ & $3-15$ \\
\hline & & $\begin{array}{l}\text { Mean inter-item } \\
\text { correlation }\end{array}$ & .38 & .62 & .34 & .42 \\
\hline & & Kolmogorov-Smirnov d & $.10^{* *}$ & $.08^{*}$ & $.14^{* *}$ & $.12^{* *}$ \\
\hline
\end{tabular}

${ }^{*} p<.05 ;{ }^{* *} p<.01$

By means of exploratory factor analysis with principal component model and varimax normalized rotation, four factors were extracted, explaining $61 \%$ of variance in total. Results of music preferences were formed for each factor by adding the assessments that saturate each of the factors. Factor structure and the characteristics of subscales are shown in Table 1.

\subsection{Procedure}

The survey was conducted in January 2014 in the university facilities according to a prearranged schedule with 20 participants in each group. The purpose of conducting the research was briefly explained to the participants, their anonymity was guaranteed, and the participants were asked to honestly and accurately answer the questions. They were 


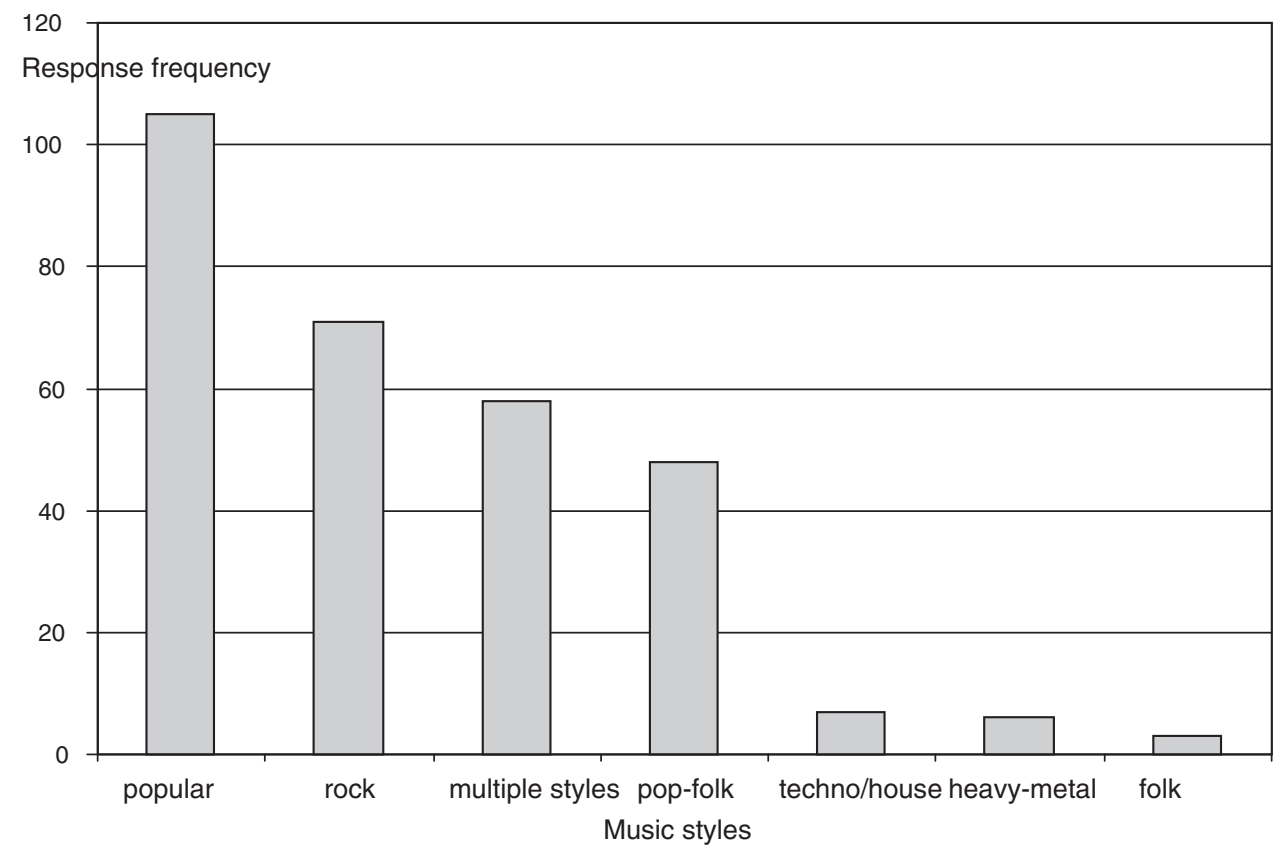

Figure 1. Music styles that participants usually listen to in leisure time $(\mathrm{N}=298)$

given instructions on how the research would be conducted, but they were not told which music styles and performers were used. The participants listened to each musical example in duration of about one minute and then assessed the degree of liking and the familiarity of each example. In order to distribute the impact of the order of listening, two rotation of musical examples sequence were performed.

\section{Results}

In order to test the first hypothesis, the participants' answers to the question what music they listen to in their leisure time were categorised. These responses are shown in Figure 1.

Figure 1 shows that participants mostly listen to popular music in their leisure time. It is followed by popular music, and in minor extent other music styles. Out of the total number of responses, 58 participants $(17 \%)$ in their free time listen to music of different styles, which means that they have multiple musical preferences with regard to musical style, rather than clearly defined preferences for musical styles. Furthermore, only one participant said that he/she does not listen to any music, which suggests that listening to music is an important element of young people's free time (Christenson \& Peterson, 1988; Schwartz \& Fouts, 2003). Music helps young people meet a wide range of social, emotional and developmental needs (Arnett, Larson \& Offer, 1995; Rubin, 1994). North, Hargreaves 
and $\mathrm{O}^{\prime}$ Neill (2000) state that music is important to adolescents because it allows them to portray an image to the outside world and satisfy their emotional needs.

In our research only one participant stated that he/she listens to classical music in leisure time, two participants stated that they listen to religious and klapa singing (klapa singing is a multipart, a capella homophonic singing tradition of the southern Croatian regions of Dalmatia. The leader of each singing group is the first tenor, followed by several tenor, baritone and bass voices), and other participants listen to other music styles, with a frequency of two or less. Given the age of the participants, these results are not surprising, but clearly point to a low representation of music styles outside the mainstream music. These results confirm the first hypothesis.

In order to test the second hypothesis and to compare the results of music preferences with regard to music styles, a Friedman ANOVA test was conducted. The results indicate a significant difference in preferences, depending on the music style (ANOVA $=123.58$; $d f=3, N=341 ; p=.000$ ). The participants expressed the highest degree of preferences for popular music (average rank $=2.84$ ) and classical music (average rank $=2.83$ ), followed by jazz and world music (average rank $=2.41$ ), while the lowest degree of preferences was obtained for heavy metal music (average rank=1.92). This confirmed the second hypothesis, which is consistent with the results of Dobrota and Reić Ercegovac (2009) who suggest that popular music is the favourite music style of the secondary school population.

According to the third hypothesis, it was presumed that the familiarity of music affects the preferences of the participants. To test this assumption, a number of tests were carried out in order to compare musical preferences of those who are familiar with that piece and those who are not. Results of these comparisons are shown in Table 2.

Out of 15 musical examples, in 12 of them it was possible to test the effect of familiarity on the assessment of liking, given the unfavourable distribution of data in three examples (Table 2). Almost all participants were familiar with those three musical examples. From a total of 12 tested musical examples, in 11 of them a significant effect of familiarity on assessment of liking was found. In seven musical examples a positive relationship between familiarity and preferences was found, but in the case of four musical examples participants who were not familiar with those examples expressed higher preferences. It should be noted that these four examples come from four different categories with respect to the musical style. It can be concluded that familiarity has an effect on the assessment of liking but this effect is not unambiguous. In some cases participants prefer familiar musical examples and in other cases those unfamiliar. Previous research results generally confirm that familiarity is positively associated with musical preferences (Peretz, Gaudreau \& Bonnel 1998; North \& Hargreaves, 2008; Dobrota \& Reić Ercegovac, 2009), although Finnäs (1989) points out that this is true in the case of sophisticated music, but not in musical examples of simpler structure.

In order to test the effect of type of secondary school education on music preferences, and since the distribution of preferences results that differed from the normal distribution (Table 1), a series of Mann-Whitney $U$ tests were conducted, the results of which are shown in Table 3.

From the results shown in Table 3, it is evident that there are no differences between the participants who attended grammar schools and those who attended vocational schools 
Table 2. The results of $t$-tests for testing the effect of familiarity of music on preference

\begin{tabular}{|c|c|c|c|c|c|c|}
\hline Performer & Music Example & Familiarity & $\mathrm{N}$ & M & $\mathrm{t}$ & df \\
\hline \multirow[t]{2}{*}{ Louis Armstrong } & \multirow[t]{2}{*}{ When You're Smiling } & known & 235 & 3.86 & \multirow[t]{2}{*}{$5.62^{*}$} & \multirow[t]{2}{*}{339} \\
\hline & & unknown & 106 & 3.15 & & \\
\hline \multirow[t]{2}{*}{ Julian Avalos } & \multirow[t]{2}{*}{ Guajira Bonita (Peru) } & known & 124 & 4.06 & \multirow[t]{2}{*}{$9.94^{*}$} & \multirow[t]{2}{*}{339} \\
\hline & & unknown & 217 & 2.83 & & \\
\hline \multirow[t]{2}{*}{ Claudia Gomez } & \multirow[t]{2}{*}{ Soltarlo (Colombia) } & known & 340 & 3.79 & \multirow[t]{2}{*}{-} & \\
\hline & & unknown & 1 & 2.00 & & \\
\hline \multirow[t]{2}{*}{ Charlie Parker } & \multirow[t]{2}{*}{ I've got Rhythm } & known & 206 & 4.05 & \multirow[t]{2}{*}{$3.28^{*}$} & \multirow[t]{2}{*}{339} \\
\hline & & unknown & 135 & 3.69 & & \\
\hline \multirow[t]{2}{*}{ Cafe Tacuba } & \multirow[t]{2}{*}{ Esa noche (Meksiko) } & known & 81 & 3.23 & \multirow[t]{2}{*}{$7.87^{*}$} & \multirow[t]{2}{*}{338} \\
\hline & & unknown & 259 & 2.08 & & \\
\hline \multirow[t]{2}{*}{ Miles Davies } & \multirow[t]{2}{*}{ Smoke gets in your eyes } & known & 110 & 2.99 & \multirow[t]{2}{*}{$-3.64^{*}$} & \multirow[t]{2}{*}{337} \\
\hline & & unknown & 229 & 3.46 & & \\
\hline \multirow[t]{2}{*}{ Iron Maiden } & \multirow[t]{2}{*}{ The Trooper } & known & 248 & 3.81 & \multirow[t]{2}{*}{$9.01^{*}$} & \multirow[t]{2}{*}{338} \\
\hline & & unknown & 92 & 2.56 & & \\
\hline \multirow[t]{2}{*}{ Judas Priest } & \multirow[t]{2}{*}{ Painkiller } & known & 327 & 2.62 & \multirow[t]{2}{*}{$-7.23^{*}$} & 338 \\
\hline & & unknown & 13 & 4.48 & & \\
\hline Black Sabbath & Paranoid & known & 31 & 2.89 & -2.7 & 338 \\
\hline & & unknown & 309 & 3.45 & & \\
\hline Melanie Fiona & Monday Morning & known & 322 & 3.51 & - & \\
\hline & & unknown & 18 & 2.67 & & \\
\hline Jay Z Alicia Keys & Empire State of Mind & known & 87 & 3.42 & $-4.8^{*}$ & 338 \\
\hline & & unknown & 253 & 4.10 & & \\
\hline Taylor Swift & You Belong With Me & known & 285 & 4.03 & $9.16^{*}$ & 338 \\
\hline & & unknown & 55 & 2.47 & & \\
\hline C. Orff & $\begin{array}{l}\text { Carmina Burana, O } \\
\text { Fortuna }\end{array}$ & known & 109 & 3.57 & $-4.58^{*}$ & 338 \\
\hline & & unknown & 232 & 4.13 & & \\
\hline Johann & Toccata and Fugue in D & known & 202 & 3.17 & $4.30^{*}$ & 338 \\
\hline Sebastian & minor, BWV 565G & & & & & \\
\hline & & unknown & 138 & 2.58 & & \\
\hline Georg F. Händel & Alleluia & known & 340 & 4.00 & - & \\
\hline & & unknown & 1 & 1.00 & & \\
\hline
\end{tabular}

$* p<.05$

in the preferences for musical styles, which rejects the fourth hypothesis. These results lead us to the necessity of reconsideration of the quality of music education in grammar schools.

Harland (2000) points out that music is one of the most popular subjects in British primary schools, but its popularity is significantly reduced in secondary school education. One possible explanation for this situation is the differences in the motivation of students for studying different subjects at different developmental stages. Furthermore, one possible explanation for the decline in popularity of music education in secondary school education is the existence of cultural dissonance between the content of secondary school music 
Table 3. Testing of the differences in music preferences with regard to the type of the secondary school education

\begin{tabular}{lllllll}
\hline \hline \multirow{2}{*}{ Preferences } & $\begin{array}{l}\text { Categories of secondary } \\
\text { school education }\end{array}$ & $\mathrm{C}$ & $\mathrm{z}$ & $\mathrm{p}$ & $\mathrm{N}_{\text {gram. }}$ & $\mathrm{N}_{\text {voc. }}$ \\
\hline Jazz and world music & $\begin{array}{l}\text { grammar } \\
\text { vocational }\end{array}$ & 3.70 & -.63 & .53 & 222 & 119 \\
Heavy-metal & 3.70 & & & & \\
grammar & 3.00 & -1.92 & .05 & 222 & 119 \\
Popular & vocational & 3.40 & & & & \\
Classical & grammar & 3.60 & -.25 & .80 & 222 & 119 \\
& vocational & 4.00 & & & & \\
& grammar & 3.80 & 1.25 & .21 & 222 & 119 \\
\hline \hline
\end{tabular}

lessons and the music that teenagers listen to which is not part of their curriculum. And, finally, a third possible explanation is based on the idea that a lack of motivation for learning music in secondary school education is the result of poor or inadequate training of music teachers. Boal-Palheiros and Hargreaves (2001) explained this situation by the fact that home music listening and school music fulfilled different functions. The participants reported that home listening was linked with enjoyment, emotional mood and social relationships, whereas school music was associated with motivation for learning and being active, and particular lesson content. In fact, most music teachers in Croatia are trained within the framework of Western artistic tradition and the question is whether they show interest towards adapting to new challenges and attempts to modernize the music syllabus.

Although over 20 years old, Ross $(1995,1998)$ pointed out that music education is one of the most unpopular subjects in secondary school, explaining this by the fact that it is not adapted to the challenges and changes of modern society in which students live. It can be explained by the fact that music education in Croatia which is not in accordance with the interests and needs of students affects its popularity, and as such has no effect on the formation of student's music preferences.

Table 4 shows the results of testing the differences in music preferences among participants who attended music school and those who did not. It is evident that the only significant difference exists in the case of preferences for jazz and world music which are higher in participants who attended music school. The fifth hypothesis is only partially confirmed, since the positive effect of attending music school exists only for one music style.

Finally, in order to investigate the influence of personal experience on music preferences, the music preferences results of the participants were compared with the frequency of attending classical music concerts (Table 5), and musical theatre productions (Table 6) in their leisure time.

Table 5 shows that there is a significant relationship between the frequency of attending classical music concerts and music preferences. Preferences were the highest for the group of the participants with the highest frequency of attending concerts. This effect has not been confirmed only in the case of preference for heavy metal music, although there is a visible 
Table 4. Testing of the differences in music preferences with regard to attending music school

\begin{tabular}{|c|c|c|c|c|c|c|}
\hline Preferences & $\begin{array}{l}\text { Attending of } \\
\text { music school }\end{array}$ & $\mathrm{C}$ & z & $p$ & $\mathrm{~N}_{\mathrm{ms}}$ & $\mathrm{N}$ \\
\hline Jazz and world music & $\begin{array}{l}\text { yes } \\
\text { no }\end{array}$ & & 2.20 & .03 & 50 & 291 \\
\hline Heavy metal & $\begin{array}{c}\text { yes } \\
\text { no }\end{array}$ & & 1.04 & .30 & 50 & 291 \\
\hline Popular & $\begin{array}{l}\text { yes } \\
\text { no }\end{array}$ & & 1.45 & .15 & 50 & 291 \\
\hline Classical & $\begin{array}{l}\text { yes } \\
\text { no }\end{array}$ & & 1.65 & .09 & 50 & 291 \\
\hline
\end{tabular}

Table 5. The comparison of music preferences with regard to frequency of attending classical music concerts (results of the Kruskal-Wallis ANOVA)

\begin{tabular}{llrll}
\hline \hline & Categories of attending & & & \\
& classical concerts & $\mathrm{N}$ & Average rank & $\mathrm{H}(3, \mathrm{~N}=341)$ \\
\hline Jazz and world music & never & 112 & 143.63 & \\
& rarely & 87 & 148.33 & $38.12^{* *}$ \\
& sometimes & 113 & 196.11 & \\
Heavy metal & 29 & 247.21 & \\
& often & 112 & 158.71 & \multirow{6}{*}{6.29} \\
& never & 87 & 163.00 & \\
Popular & rarely & 113 & 181.88 & \\
& sometimes & 29 & 200.19 & \\
& often & 112 & 170.27 & \\
& never & 87 & 177.92 & \\
Classical & 113 & 179.80 & \\
& rarely & 29 & 118.79 & \\
& sometimes & 112 & 150.37 & \\
& often & 87 & 152.72 & \\
& never & 113 & 193.78 & \\
& rarely & 29 & 216.74 & \\
& sometimes & & &
\end{tabular}

${ }^{*} p<.05 ;{ }^{* *} p<.01$

similar trend in the results. The difference is most obvious in preference for classical music, jazz and world music that are significantly more preferred by participants who frequently attend concerts in their free time.

Furthermore, attending musical theatre productions (Table 6) cannot be linked to preference for heavy metal and pop music, but again it was shown that participants who frequently attend classical music productions express significantly greater preference for jazz music and world music. On the other hand, the frequency of attending musical 
Table 6. The comparison of music preferences with regard to the frequency of attending musical theatre productions (results of the Kruskal-Wallis ANOVA)

\begin{tabular}{|c|c|c|c|c|}
\hline & $\begin{array}{l}\text { Categories of attending } \\
\text { musical theatre } \\
\text { productions }\end{array}$ & $\mathrm{N}$ & Average rank & $\mathrm{H}(3, \mathrm{~N}=341)$ \\
\hline \multirow[t]{4}{*}{ Jazz and world music } & never & 38 & 176.32 & \\
\hline & rarely & 65 & 158.61 & $10.66^{*}$ \\
\hline & sometimes & 205 & 165.71 & \\
\hline & often & 33 & 222.14 & \\
\hline \multirow[t]{4}{*}{ Heavymetal } & never & 38 & 177.68 & \\
\hline & rarely & 65 & 175.91 & 0.74 \\
\hline & sometimes & 205 & 167.28 & \\
\hline & often & 33 & 176.73 & \\
\hline \multirow[t]{4}{*}{ Popular } & never & 38 & 162.10 & \\
\hline & rarely & 65 & 167.83 & 3.87 \\
\hline & sometimes & 205 & 177.94 & \\
\hline & often & 33 & 144.35 & \\
\hline \multirow[t]{4}{*}{ Classical } & never & 38 & 162.96 & \\
\hline & rarely & 65 & 201.48 & $11.62^{* *}$ \\
\hline & sometimes & 205 & 158.97 & \\
\hline & often & 33 & 194.94 & \\
\hline
\end{tabular}

${ }^{*} p<.05 ;{ }^{* *} p<.01$

productions proved significant for the preferences for classical music. However, subsequent comparison of the groups showed that those participants who rarely attend musical productions showed significantly greater preferences for classical music compared to those who sometimes visited musical theatre productions while among other groups there were not statistically significant differences.

\section{Conclusion}

The results of this study suggested that music, especially popular music, plays an important role in the lives of young people. Furthermore, the hypothesis of a relationship between music preferences and familiarity of musical works is partially confirmed. A significant relationship between the frequency of attending classical music concerts and musical preferences was found, especially in the case of classical music, jazz and world music. These results are consistent with the Reciprocal feedback model of musical response (Hargreaves, Miell \& MacDonald, 2005).

One of the limitations of our research is the fact that our hypothesis tests the attendance at a limited range of events, such as attendance of classical music concerts and musical theatre productions. Another limitation is a very limited sample of music used in the research. To get a real feel for music preferences it would have been useful to use qualitative 
methods that encouraged the participants to feel they had agency to share their own musical preferences outside the structural quantitative boundaries imposed by the researches.

The relationship between the type of music education and music preferences of the participants was not found. One of the most important goals of music education should be to introduce students to a variety of musical styles, cultivating their musical taste. Music preferences for unfamiliar music increase after repeated exposure to such music and learning about that music. As pointed out by Fung (1994), music preferences are an important mediator in the process of music education and the 'springboard' for further musical study. If that is correct, further research should explain why is it possible that grammar school students, compared to vocational school students, do not show higher preferences for classical music, as well as for other musical styles? It is possible that the cause of the problem lies in the conception of music education in the Croatian schools. Music education in the Croatian grammar schools is designed according to a diachronic model, in which 'the program generally follows a chronological course of the development of music and its style', so in the first grade of high school education students learn about 'development of music from its origins to the Renaissance (until the end of the $16^{\text {th }}$ century)'. In the second grade they learn about 'Baroque, Galant style and Viennese classic (the entire $17^{\text {th }}$ until $19^{\text {th }}$ century)', in the third grade students learn about the period 'from Romanticism to Impressionism (musical art in the $19^{\text {th }}$ century)', and in the fourth grade about 'developmental directions of musical art in the $20^{\text {th }}$ century' (Curriculum for grammar school. Music education, 1999, p. 77). The main drawback of this conception of music education is that it is not interesting to students and that it ' ... offers music that is contrary to their actual, potential and desirable musical interests, especially at the beginning of learning, which, in turn, can have a negative motivational effect on later grades' (Rojko, 2001, p.6). As further disadvantages of that conception Rojko (2001) cites extensiveness of the content, verbalism at the expense of the music, and the conversion of music education in a relatively rigid scheme.

In contrast to this model, in the foreground of the synchronic model is music, not the chronological sequence, which results in attractiveness and diversity of music education, so the verbalization of music can be avoided. It is possible that the organization of music education according to the synchronic model would represent a step forward in solving the problem of the conception of music education. We are surprised by the fact that participants who attended music school, compared to participants without additional music education, do not show greater preferences for classical music. The possible explanation for these findings lies in the fact that such schools are exclusively oriented towards the development of musical skills during instrument/singing and solfeggio lessons, while the aesthetic education of the students in terms of developing their musical taste, is not in the foreground.

The problem of the conception of music education is a universality and appears in almost all educational systems and in different national contexts. Leshkova-Zelenkovska and Islam (2013) also emphasize the need to redefine the curriculum of music education in the general school system. North, Hargreaves and O'Neill (2000) consider that one of the solutions to the problem of the unattractiveness of music education in secondary school can be the approach in which teachers focus more on music that is listened to and performed outside regular school. This would mean linking music education with popular music styles but also with different world music which would develop tolerance 
towards diversity and raise intercultural awareness among young population. In this way, the motivation and interest of students would become increased and an absurd situation in which music has such an important role in the lives of young people, while at the same time music education is one of the least popular subjects, can be transcended.

\section{Note}

1 Data used in this research were partly collected within the research project whose aim was to investigate the relationship between music and visual art preferences and different individual characteristics of the participants.

\section{References}

ARNETT, J. J., LARSON, R. \& OFFER, D. (1995) Beyond effects: Adolescents as active media users. Journal of Youth and Adolescence, 24, 511-518. doi: 10.1007/BF01537053.

BERLYNE, D. E. (1971) Aesthetics and Psychobiology. New York: Appleton-Century-Crofts.

BOAL-PALHEIROS, G. M. \& HARGREAVES, D. J. (2001) Listening to music at home and at school. British Journal of Music Education, 18, 103-118. doi: 10.1017/S0265051701000213.

CHRISTENSON, P. G. \& PETERSON, J. B. (1988) Genre and gender in the structure of music preferences. Communication Research, 15, 282-301. doi: 10.1177/009365088015003004.

COLARDYN, D. \& BJORNAVOLD, J. (2004) Validation of formal, non-formal and informal learning: policy and practices in EU Member States. European Journal of Education, 39, 69-89. doi: 10.1111/j.01418211.2004.00167.x.

CROWTHER, R. D. \& DURKIN, K. (1982) Sex- and age-related differences in musical behaviour, interests and attitudes towards music of 232 secondary school students. Educational Studies, 8, 131-139. doi: $10.1080 / 0305569820080206$.

Curriculum for grammar school. Music education. 1999. Zagreb: Glasnik Ministarstva prosvjete i sporta Republike Hrvatske.

DOBROTA, S. \& REIĆ ERCEGOVAC, I. (2009) Adolescents' musical preferences with regard to some sociodemographic variables. Odgojne Znano, 2, 381-398.

ECCLES, J., WIGFIELD, A. H., RENA, D. \& BLUMENFELD, P. (1993) Age and gender differences in children's self-and task perceptions during elementary school. Child Development, 64, 830-847. doi: 10.1111/j.1467-8624.1993.tb02946.x.

FINNÄS, L. (1989) How can musical preferences be modified? A research review. Bulletin of the Council for Research in Music Education, 102, 1-58.

FUNG, V.C. (1994) Musicians' and nonmusicians' preferences for world musics: Relation to musical characteristics and familiarity. Journal of Research in Music Education, 44, 60-83. doi: $10.2307 / 3345414$.

GETZ, R. P. (1966) The effects of repetition on listening response. Journal of Research in Music Education, 14, 178-192. doi: 10.2307/3344051.

GREEN, L. (2008) Music, Informal Learning and the School: A New Classroom Pedagogy. Hampshire and Burlington: Ashgate.

HARGREAVES, D. J. (1982) The development of aesthetic reactions to music. Psychology of Music, Special issue, 51-54.

HARGREAVES, D. J., COMBER, C. J. F. \& COLLEY, A. M. (1995) Effects of age, gender, and training on the musical preferences of British secondary school students. Journal of Research in Music Education, 43, 242-250. doi: 10.2307/3345639. 
HARGREAVES, D. J., MIELL, D. E. \& MACDONALD, R. A. R. (2005) How do people communicate using music? In D. E. Miell, R. A. R. MacDonald \& D. J. Hargreaves (Eds.), Musical Communication (pp. 1-25). Oxford: Oxford University Press.

HARGREAVES, D. J., NORTH, A. C. \& TARRANT, M. (2006) The development of musical preference and taste in childhood and adolescence. In G. McPherson (Ed.), The Child as Musician: A Handbook of Musical Development (pp. 135-154). Oxford: Oxford University Press.

HARLAND, J. (2000) Arts Education in Secondary School: Effects and Effectiveness. Slough: NFER.

LEBLANC, A. (1991) Effect of maturation/aging on music listening preference: A review of the literature. Paper presented at the Ninth National Symposium on Research in Music Behavior, School of music, Michigan State University, Cannon Beach, Oregon, March 7-9.

LESHKOVA-ZELENKOVSKA, S. \& ISLAM, A. (2013) The impact of music education on the preference of musical genres in the Republic of Macedonia. Journal of Teacher Education, 2, 135-141.

MARTINDALE, C. \& MOORE, K. (1988) Priming, prototypicality, and preference. Journal of Experimental Psychology: Human Perception and Performance, 14, 661-670. doi: 10.1037//0096-1523.14. 4.661.

NORTH, A.C. \& HARGREAVES, D.J. (2007a) Lifestyle correlates of musical preference: 1. Relationships, living arrangements, beliefs, and crime. Psychology of Music, 35, 58-87. doi: 10.1177/0305735607068888.

NORTH, A. C. \& HARGREAVES, D. J. (2007b) Lifestyle correlates of musical preference: 2. Media, leisure time and music. Psychology of Music, 35, 179-200. doi: 10.1177/0305735607070302.

NORTH, A.C. \& HARGREAVES, D.J. (2007c) Lifestyle correlates of musical preference: 3. Travel, money, education, employment and health. Psychology of Music, 35, 473-497. doi: 10.1177/0305735607072656.

NORTH, A. C. \& HARGREAVES, D. J. (2008) The Social and Applied Psychology of Music. New York: Oxford University Press.

NORTH, A. C., HARGREAVES, D. J. \& O'NEILL, S. A. (2000) The importance of music to adolescents. British Journal of Education Psychology, 70, 255-272. doi: 10.1348/000709900158083.

PALMQUIST, J. E. (1990) Apparent time passage and music preference by music and nonmusic majors. Journal of Research in Music Education, 38, 206-214. doi: 10.2307/3345184.

PERETZ, I., GAUDREAU, D. \& BONNEL, A.-M. (1998) Exposure effects on music preference and recognition. Memory \& Cognition, 26, 884-902. doi: 10.3758/BF03201171.

REIĆ ERCEGOVAC, I. \& DOBROTA, S. (2011) The relationship between musical preferences, sociodemographic characteristics and Big Five personality traits. Psihologijske teme, 20, 47-66.

ROBINSON, T. O., WEAVER, J. B. \& ZILLMANN, D. (1996) Exploring the relation between personality and the appreciation of rock music. Psychological Report, 78, 259-269. doi: 10.2466/pr0.1996.78. 1.259 .

ROJKO, P. (2001) History of music in music school and grammar school. Tonovi. Časopis glazbenih i plesnih pedagoga, 1/2, 3-19.

ROSS, M. (1995) What's wrong with school music? British Journal of Music Education, 12, 185-201. doi: $10.1017 /$ S0265051700002692.

ROSS, M. (1998) Missing solemnis: Reforming music in schools. British Journal of Music Education, 15, 255-262. doi: 10.1017/S0265051700003934

RUBIN, A. M. (1994) Media uses and effects: A uses-and-gratifications perspective. In J. Bryant \& D. Zillman (Eds.) Media Effects: Advances in Theory and Research (pp. 417-436). Hillsdale, NJ, England: Lawrence Erlbaum Associates, Inc.

SCHWARTZ, K. D. \& FOUTS, G. T. (2003) Music preferences, personality style, and developmental issues of adolescents. Journal of Youth and Adolescence, 32, 205-213. doi: 10.1023/A:1022547520656 
TEO, T., HARGREAVES, D. J. \& LEE, J. (2008) Musical preference, identification, and familiarity. A multicultural comparison of secondary students from Singapore and the United Kingdom. Journal of Research in Music Education, 56, 18-32. doi: 10.1177/0022429408322953.

VITALE, J. L. (2011) Formal and informal music learning: attitudes and perspectives of secondary school non-music teachers. International Journal of Humanities and Social Sciences, 1, 1-14.

Snježana Dobrota works as Associate Professor at the Faculty of Humanities and Social Sciences, University of Split, where she teaches courses in Didactics of Music. She obtained her PhD in pedagogy at the Faculty of Humanities and Social Sciences, University of Zagreb, Croatia in 2008. She has published scientific articles and participated with presentations in international scientific conferences. Her main research interests are in the area of didactics of music, intercultural music education and psychology of music.

Ina Reić Ercegovac obtained her PhD in developmental psychology at the University of Zagreb, Croatia in 2010. She currently works as Assistant Professor at the Faculty of Humanities and Social Sciences, University of Split, where she teaches courses in developmental psychology, child abuse and neglect, attachment across lifespan, and psychology of teaching. Since 2012 she is the Head of the Centre for Research and Development of Lifelong Learning at the Faculty of Humanities and Social Sciences, University of Split. She has published over 40 scientific articles and participated with presentations in 20 international scientific conferences. Her main research interests are in the area of parenting, attachment, school achievement, and psychology of music. 